\title{
TINGKAT PENGETAHUAN IBU HAMIL TENTANG ANEMIA DI RS. PANTI WILASA CITARUM SEMARANG
}

\author{
Nor Tri Astuti Wahyuningsih* \\ STIKes Panti Wilasa Semarang. Jl. Ciliwung IX No.1 Semarang. \\ norast_ent@yahoo.co.id
}

\begin{abstract}
ABSTRAK
Latar Belakang : AKI Indonesia sebesar 359/100.000 kelahiran hidup menurut SDKI tahun 2012. Sedangkan dari Dinkes Kesehatan Provinsi Jawa Tengah tahun 2012 AKI sebesar 116,34/100.000 kelahiran hidup. Penyebab terjadinya AKI terbesar di indonesia adalah perdarahan, kanker, ginjal, jantung, TBC. Anemia pada ibu hamil menjadi penyebab utama terjadinya perdarahan dan infeksi yang merupakan faktor kematian utama ibu di Indonesia. Berdasarkan Direktorat Jenderal Gizi dan Kesehatan Ibu-Anak Kementerian Kesehatan pada tahun 2012 mancatat 1 dari 2 wanita beresiko anemia.

Tujuan : untuk mengetahui gambaran tingkat pengetahuan dan karakteristik ibu hamil tentang anemia di RS. Panti Wilasa Citarum Semarang.

Metode : Penelitian ini merupakan penelitian deskriptif dengan pendekatan cross sectional. Jumlah populasi sebanyak 34 ibu hamil di RS. Panti Wilasa Citarum Semarang diambil dengan teknik sampling total atau memasukkan semua populasi sebagai sampel. Metode pengumpulan data dengan menggunakan wawancara terpimpin. Instrumen penelitian yang digunakan adalah kuesioner, dengan analisis data menggunakan Microsoft Excel 2013.

Hasil: $61,8 \%$ responden memiliki pengetahuan cukup, 88,3\% rentang usia responden 20-35 tahun, 64,7\% responden berlatar pendidikan SMA, 94\% sebagian besar paritas responden $<3$, dan $58,9 \%$ responden bekerja sebagai pegawai swasta.

Kesimpulan : Tingkat pengetahuan ibu hamil tentang anemia di RS. Panti Wilasa Citarum Semarang yaitu pada kategori cukup sebanyak 21 responden $(61,8 \%)$.
\end{abstract}

Kata kunci : Pengetahuan, Karakteristik, Anemia 


\begin{abstract}
Background: Based on Indonesian Demographic and Health Survey (IDHS), Maternal Mortality Rate (MMR) in Indonesia in 2012 was 359/100,000 live births. While the Health of Health Office of Central Java province in 2012 amounted to 116.34 AKI / 100,000 live births. The main causes of MMR in Indonesia are bleeding, cancer, kidney disease, heart disease, tuberculosis. Anemia in pregnant women is a major cause of bleeding and infection thatr are two major factors of maternal mortality in Indonesia. Based on General Directorate of Nutrition and Mother and Child Health of the Ministry of Health, in 2012 it was recorded that 1 of 2 women was at risk of anemia.

Objective: to describe the level of knowledge on anemia and the characteristics of pregnant women at Panti Wilasa Citarum Semarang Hospotal.

Methods: This study was a descriptive study with cross sectional approach. Total population were 34 pregnant women at Panti Wilasa Citarum Semarang Hospotal, Rowoboni Village Semarang District, who were taken with total sampling technique or took all of the population as the samples. The data collection used guided interviews. The study instrument used here was a questionnaire, and the data analysis used Microsoft Excel 2013.

Results: $61,8 \%$ of the respondents had moderate knowledge, $88,3 \%$ of the respondents age ranged from 20-35 years, 64,7\% of the respondents had a High School, 94\% of the respondents had a parity of $<3$, and 58,9\% of the respondents worked as private employees. Conclusion: The level of knowledge of the pregnant women on anemia at Panti Wilasa Citarum Semarang Hospotal was in the moderate category as many as 21 respondents $(61,8 \%)$.
\end{abstract}

Keywords: Knowledge, Characteristics, Anemia

\section{PENDAHULUAN}

Berdasarkan hasil survei Demografi dan Kesehatan Indonesia (SDKI) tahun 2012, menunjukkan Angka Kematian Ibu 359/100.000 kelahiran hidup. Angka kematian Ibu ini sedikit menurun dibandingkan dengan survei SDKI tahun 1991/100.000. Sementara pada tahun 2015 target global MDGs (Millenium Development Goals) ke-5 adalah menurunkan AKI menjadi 102/100.000 kelahiran hidup. Mengacu dari kondisi saat ini untuk pencapaian target MDGs ke-5 yaitu untuk menurunkan AKI adalah off track yang artinya adalah diperlukan kerja keras dan sungguh untuk mencapainya (Kemenkes RI, 2012).
Menurut Dinkes Provinsi Jawa Tengah pada tahun 2012, Angka Kematian Ibu sebesar 116,34/100.000 kelahiran hidup, terjadi peningkatan jika dibandingkan dengan Angka Kematian Ibu pada tahun 2011 yaitu sebesar 116,01/100.000 kelahiran hidup. Adapun penyebab dari kematian ibu selama tahun 2010 - 2013 tetap sama yaitu perdarahan, kanker, ginjal, jantung, tuberkulosis, dan penyakit yang diderita ibu seperti anemia dan hipertensi (Dinkes Provinsi Jawa Tengah, 2015).

Terkait dengan kesehatan ibu Riskasdes 2013 menunjukkan cakupan pelayanan antenatal bagi ibu hamil meningkat. Hal tersebut memperlihatkan semakin membaiknya akses masyarakat terhadap pelayanan antenatal oleh 
petugas kesehatan meningkat dari $92,7 \%$ pada tahun 2010 menjadi 95,2\% pada tahun 2013. Cakupan tersebut juga sejalan dengan ibu hamil yang mendapatkan pelayanan antenatal pertama pada trimester pertama $(\mathrm{k} 1)$ yaitu 72,3\% pada tahun 2010 menjadi 81,3\% pada tahun 2013. Tidak menutup kemungkinan jika cakupan pelayanan antenatal yang dilakukan sekurangkurangnya 4 kali (k4) juga meningkat dari $61,4 \%$ pada tahun 2010 menjadi $70,0 \%$ pada tahun 2013. Akan tetapi disamping peningkatan akses dan kualitas masyarakat yang semakin membaik untuk upaya peningkatan kesehatan ibu, Riskasdes pada tahun 2013 masih mempunyai tantangan untuk menurunkan proporsi anemia pada ibu hamil yaitu terdapat $37,1 \%$ ibu hamil mengalami anemia dengan kadar $\mathrm{Hb}$ kurang dari 10 gr/dl, dengan proporsi yang hampir sama antara di kawasan perkotaan $(36,4 \%)$ dan pedesaan (37,8\%) (Riskasdes, 2013).

Anemia dalam kehamilan diklasifikasikan menjadi 4, yaitu anemia Defisiensi Besi $(62,3 \%)$ terjadi karena kekurangan zat besi dalam darah, anemia Megaloblastik karena kekurangan defisiensi asam folat dan vitamin B12, anemia Hiploplastik dan anemia Aplastiksebanyak $8 \%$ terjadi karena sumsum tulang belakang kurang mampu membuat sel-sel baru, anemia Hemolitik sebanyak $0,7 \%$ terjadi karena penghancuran sel darah merah berlangsung lebih cepat daripada pembuatannya. Dari salah satu klasifikasi anemia dalam kehamilan adalah Defisiensi Zat Besi (Proverawati, 2009). Ibu hamil dianjurkan untuk banyak mengkonsumsi makanan yang kaya dengan zat besi, asam folat serta vitamin B12. Dalam pemberian makanan untuk ibu hamil yang mengalami anemia sebaiknya dengan banyak kandungan seperti protein, zat besi (Fe), asam folat, dan vitamin B12 (Muliarini, 2010).

Pada dasarnya ibu hamil yang anemia akan mengalami banyak gangguan seperti, mudah pusing, pingsan, pertumbuhan janin terlambat,lahir prematur, lahir dengan kadar zat besi kurang atau lahir dengan cacat bawaan, dan mudah keguguran atau bisa dikatakan dalam proses persalinan nanti akan mengalami waktu yang lama di karenakan kontraksi yang tidak maksimal dan terjadi perdarahan setelah persalinan yang akan mengancam jiwa ibu.Hal tersebut yang kurang di perhatikan oleh calon ibu, dikarenakan calon ibu beranggapan jika mengalami hal yang demikian dikatakan wajar atau bawaan dari bayinya (Muliarini, 2010).

Anemia dalam kehamilan dapat berpengaruh buruk terutama saat kehamilan, persalinan dan nifas. Pengaruh anemia selama kehamilan dapat berupa abortus, persalinan prematur, ketuban pecah dini, dan gangguan pertumbuhan janin. Pengaruh anemia selama persalinan adalah dapat berupa gangguan his dan kekuatan mengejan, partus lama pada kala I, partus lama yang melelahkan dan memerlukan tidakan operasi kebidanan pada kala II, retensio plasenta dan perdarahan post partum akibat atonia uteri pada kala III, perdarah post partum sekunder dan atonia uteri pada kala IV. Pengaruh anemia selama nifas adalah subinvolusi uteri, perdarahan post partum, infeksi puerperium atau nifas, pengeluaran ASI berkurang, anemia pada kala nifas, dan penyembuhan luka perineum lama (Manuaba, 2007).

Data yang penulis peroleh dari RS. Panti Wilasa Citarum Semarang adalah 194 ibu hamil, diantaranya 63 ibu hamil. Dari jumlah ibu hamil tersebut didapatkan, 37 orang $(58,7 \%)$ mengalami 
anemia ringan, 7 orang $(11,11 \%)$ mengalami anemia sedang, 2 orang $(3,17 \%)$ mengalami anemia berat, dan 17 orang $(26,9 \%)$ tidak mengalami anemia. Peran seorang bidan memiliki fungsi sebagai pelaksana yaitu melakukan asuhan kebidanan untuk proses kehamilan normal, kehamilan dengan kasus patologi tertentu dan kehamilan dengan resiko tinggi.

AKI di Indonesia saat ini masih tinggi dan sangat mengkhawatirkan. Salah satu penyebab dari AKI tersebut adalah anemia selama kehamilan, anemia ini membawa pengaruh buruk terhadap kehamilan, persalinan dan nifas. Dimana anemia ini paling banyak dikarenakan kekurangan defisiensi besi yang mengakibatkan ibu hamil mengalami banyak gangguan seperti, mudah pusing, pingsan, pertumbuhan janin terlambat, lahir prematur, lahir dengan kadar zat besi kurang atau lahir dengan cacat bawaan, dan mudah keguguran atau bisa dikatakan dalam proses persalinan nanti akan mengalami waktu yang lama di karenakan kontraksi yang tidak maksimal dan terjadi perdarahan setelah persalinan yang akan mengancam jiwa ibu. Hal tersebut yang kurang diperhatikan oleh calon ibu, dikarenakan calon ibu beranggapan jika mengalami hal yang demikian dikatakan wajar atau bawaan dari bayinya. Berdasarkan latar belakang di atas, maka penulis dapat mengambil suatu rumusan masalah yaitu : Bagaimana Gambaran Tingkat Pengetahuan Ibu Hamil Tentang Anemia di RS. Panti Wilasa Citarum Semarang?

\section{METODE PENELITIAN Metode}

Penelitian ini merupakan penelitian deskriptif dengan pendekatan waktu secara Cross Sectional.

\section{Tempat dan Waktu Penelitian}

Penelitian dilakukan di RS. Panti Wilasa Citarum Semarang pada bulan Oktober 2018.

\section{Variabel Penelitian dan Definisi Operasional}

Variabel dalam penelitian ini tingkat pengetahuan ibu tentang anemia, umur, paritas, pendidikan dan pekerjaan.

\section{Populasi dan Sampel}

Dalam penelitian ini peneliti mengambil seluruh populasi ibu hamil yang datang periksa di Poliklinik RS. Panti Wilasa Citarum Semarang, yaitu 34 ibu hamil pada bulan Oktober 2018.

\section{Pengumpulan Data}

Sumber data yang dikumpulkan adalah sumber data primer dan sekunder. Data primer melalui wawancara terpimpin kepada responden dengan menggunakan kuesioner dan data sekunder dengan mengumpulkan data dari catatan ibu hamil di Poliklinik RS. Panti Wilasa Citarum Semarang.

\section{HASIL}

Hasil penelitian menunjukkan bahwa sebagian besar responden 21 $(61,8 \%)$ memiliki tingkat pengetahuan yang cukup tentang anemia. Distribusi responden berdasarkan tingkat pengetahuan yang cukup tentang anemia dapat dilihat pada tabel 1 .

Tabel 1. Distribusi Frekuensi Tingkat Pengetahuan.

\begin{tabular}{ccc}
\hline $\begin{array}{c}\text { Tingkat } \\
\text { Pengetahuan }\end{array}$ & $\begin{array}{c}\text { Frekuensi } \\
(\mathrm{n})\end{array}$ & $\begin{array}{c}\text { Persentase } \\
(\%)\end{array}$ \\
\hline Baik & 12 & 35,3 \\
Cukup & 21 & 61,8 \\
Kurang & 1 & 2,9 \\
\hline Total & 34 & 100 \\
\hline
\end{tabular}


Pada penelitian ini rentang usia responden 20-35 tahun sebanyak 29 responden $(85,3 \%)$. Distribusi frekuensi responden berdasarkan usia dapat dilihat pada tabel 2.

Tabel 2. Distribusi responden berdasarkan umur

\begin{tabular}{ccc}
\multicolumn{3}{c}{ umur } \\
\hline Umur & Frekuensi & Persentase $(\%)$ \\
\hline$<20$ & 2 & 5,9 \\
$20-35$ & 29 & 85,3 \\
$>35$ & 3 & 8,8 \\
\hline Total & 34 & 100 \\
\hline
\end{tabular}

Hasil penelitian menunjukkan bahwa sebagian besar responden 24 $(64,7 \%)$ berlatar belakang Pendidikan Menengah Atas (SMA). Distribusi responden berdasarkan pendidikan dapat dilihat pada tabel 3 .

Tabel 3. Distribusi Responden Berdasarkan Pendidikan.

\begin{tabular}{ccc}
\hline Pendidikan & $\begin{array}{c}\text { Frekuensi } \\
(\mathrm{n})\end{array}$ & $\begin{array}{c}\text { Persentase } \\
(\%)\end{array}$ \\
\hline $\begin{array}{c}\text { Perguruan Tinggi } \\
\text { Pendidikan }\end{array}$ & 5 & 14,7 \\
Menengah Atas & 22 & 64,7 \\
Pendidikan Dasar & 7 & 20,6 \\
\hline Total & 34 & 100 \\
\hline
\end{tabular}

Hasil penelitian gambaran tingkat pengetahuan ibu hamil tentang anemia berdasarkan paritas menunjukkan bahwa sebagian responden (94\%) atau sebanyak 32 responden memiliki anak sebanyak $<3$. Distribusi responden berdasarkan paritas dapat dilihat pada tabel 4 .

\section{Tabel 4. Distribusi Responden Berdasarkan Paritas}

\begin{tabular}{ccc}
\hline Paritas & Frekuensi & Persentase $(\%)$ \\
\hline$<3$ & 32 & 94 \\
$\geq 3$ & 2 & 6 \\
\hline Total & 34 & 100 \\
\hline
\end{tabular}

Hasil penelitian gambaran tingkat pengetahuan ibu hamil tentang anemia berdasarkan status pekerjaan menunjukkan bahwa sebagian besar responden $20(58,9 \%)$ bekerja sebagai pegawai swasta. Distribusi responden berdasarkan pekerjaan dapat dilihat pada tabel 5.

Tabel 5. Distribusi Responden Berdasarkan Pekerjaan.

\begin{tabular}{ccc}
\hline Pekerjaan & $\begin{array}{c}\text { Frekuensi } \\
(\mathrm{n})\end{array}$ & $\begin{array}{c}\text { Persentase } \\
(\%)\end{array}$ \\
\hline Pegawai Swasta & 20 & 58,9 \\
Pedagang & 8 & 23,5 \\
Tidak Bekerja & & 17,6 \\
\hline (IRT) & 6 & 100 \\
\hline Total & 34 &
\end{tabular}

\section{PEMBAHASAN}

\section{Tingkat Pengetahuan Ibu Hamil Tentang Anemia}

Pada hasil penelitian yang dilakukan terhadap 34 responden didapatkan bahwa sebagian besar memiliki pengetahuan yang cukup yaitu 21 responden $(61,8 \%)$. Sedangkan yang memiliki tingkat pengetahuan baik sebanyak 12 responden $(35,3 \%)$.

Menurut penelitian Maulida NS yang berjudul Hubungan Tingkat Pengetahuan Tentang Anemia Pada Ibu Hamil Dengan Kepatuhan Dalam Mengkonsumsi Tablet Besi (Fe) Di Puskesmas Keling II Kabupaten Jepara memiliki pengetahuan yang cukup terhadap anemia, pengetahuan yang cukup dipengaruhi oleh banyaknya jumlah responden yang termasuk dalam kelompok umur 20-35 tahun, terdapat $63,8 \%$ responden termasuk dalam umur tersebut. Pada kelompok umur tersebut, penjelasan dan informasi yang disampaikan oleh tenaga kesehatan dan berbagai media masih memungkinkan 
diterima dan dipahami dengan mudah. Tingkat pengetahuan dipengaruhi oleh tingkat pendidikan formal. Terdapat 52,2\% responden berlatar belakang pendidikan dasar sehingga mayoritas responden memiliki pengetahuan yang cukup (Maulida, 2013).

Hal ini berbeda dengan hasil penelitian sebelumnya yang diteliti oleh Wahyu Tri Utami yang berjudul Gambaran Pengetahuan Ibu Hamil Tentang Manfaat Tablet Fe Di Desa Candi, Kecamatan Ampel, Kabupaten Boyolali diketahui bahwa sebagian responden memiliki pengetahuan yang kurang yaitu sebanyak 38 (71,7\%) ibu berpengetahuan kurang. Hal ini dikarenakan mayoritas ibu hamil di Desa Candi Kecamatan Ampel mempunyai tingkat pendidikan rendah dan mereka kurang memahami penjelasan dari tenaga kesehatan. Pendidikan rendah akan menghambat perkembangan sikap seseorang terhadap nilai baru yang diperkenalkan (Wahyu Tri Utami, 2013) . Tingkat pendidikan berpengaruh pada pengetahuan sehingga dalam menerima informasi dan memahami pengetahuan tentang manfaat tablet $\mathrm{Fe}$ kurang (Notoatmodjo, 2008).

Dalam mengukur pengetahuan responden, peneliti menggunakan kuisioner sejumlah 28 pernyataan. Dari uraian setiap soal responden sudah mengetahui dan memahami tentang anemia pada ibu hamil. Namun terdapat soal yang hanya bisa dijawab dengan benar oleh 16 responden yang diuraikan pada soal nomor 2 yaitu mengenai gejala dan tanda anemia, hal tersebut disebabkan karena kurang jelasnya informasi yang didapatkan kepada responden dan juga responden menganggap gejala dan tanda tersebut merupakan hal yang biasa yang tidak perlu di khawatirkan. Perlu diketahui bahwa gejala dan tanda anemia adalah cepat lelah, pusing, mudah pingsan, malnutrisi, sering pusing, mata berkunang-kunang, malaise, lidah luka, nafsu makan turun, konsentrasi hilang, nafas pendek. Selain itu akibat apabila ibu tidak mengetahui tanda dan gejala anemia maka dampaknya akan pada kehamilan seperti aborstus, pada persalinan terjadi gangguan his, dan pascapersalinan terjadinya retensio plasenta dan subinvolusi uteri.

Sementara pertanyaan tentang pengetahuan dinomor 17 mengenai efek samping sebanyak 16 responden $(47 \%)$ dapat menjawab dengan benar. Hal tersebut dikarenakan penjelasan yang didapatkan kurang walaupun demikian, sebagian ibu juga menyebutkan bahwa tidak semua petugas kesehatan menjelaskan kemungkinan timbulnya efek samping akibat minum tablet tambah darah. Namun diakui oleh informanapabila penjelasan tersebut diberikan sebelumnya, informan akan merasa lebih tenang dan tidak khawatir saat efek samping timbul. Ini sesuai dengan penelitian Titaley CR, dkk yang berjudul Persepsi Ibu Hamil Dan Nifas tentang Anemia Dan Konsumsi Tablet Tambah Darah Selama Kehamilan Studi Kualitatif di Kabupaten Purwakarta Dan Lebak menunjukkan bahwa informasi terkait efek samping tablet tambah darah masih dianggap kurang (Titaley CR, 2014).

Selain itu pada soal nomor 19 mengenai makanan yang mengandung zat besi, ada 20 responden (59\%) menyatakan tidak mengetahui tentang bahan makanan yang mengandung tablet zat besi. Ini dikarenakan kurangnya informasi atau pemahaman terhadap konsumsi makanan yang mengandung zat besi. Hal ini sesuai dengan penelitian Erwin Prapitasari tahun 2003 tentang 
Hubungan Antara Tingkat Pengetahuan Anemia Dan Sikap Ibu Hamil Dalam Mengkonsumsi Tablet $\mathrm{Fe}$ Dengan Kejadian Anemia Di Wilayah Kerja Puskesmas Kerjo Kabupaten Karanganyar, bahwa pengetahuan ibu hamil yang kurang tentang anemia dan faktor yang mempengaruhinya akan berpengaruh pada kurangnya konsumsi makanan yang mengandung zat besi sehingga menyebabkan ibu hamil akan mengalami anemia yang pada akhirnya akan berpengaruh terhadap pertumbuhan dan perkembangan janin. Perlu diketahui bahwa mengkonsumsi makanan yang mengandung zat besi sangat penting bagi ibu hamil karena untuk pembentukan sel darah merah.

Pada pertanyaan tentang pengetahuan yang dijawab responden pada soal nomer 21 tentang pemeriksaan kadar $\mathrm{Hb}$ selama hamil, 21 responden (62\%) menyatakan belum pernah mendapatkan informasi tentang pemeriksaan $\mathrm{Hb}$. Hal ini sesuai dengan hasil penelitian menurut Happy Dwi Aprilina dkk tentang Penyuluhan Kesehatan Dan Deteksi Anemia Bagi Ibu Hamil Disokaraja Tengah Banyumas, bahwa kurangnya informasi tentang anemia dan kurangnya pemahaman ibu tentang pentingnya pemeriksaan kehamilan secara rutin serta perlunya pemeriksaan $\mathrm{Hb}$ untuk ibu hamil. Pemeriksaan $\mathrm{Hb}$ merupakan parameter yang digunakan untuk menetapkan prevalensi anemia dan sebagai senyawa pembawa oksigen pada sel darah merah (Happy Dwi Aprilina, 2015).

Pada soal nomer 23 tentang akibat yang timbul pada saat ibu bersalin yang kekurangan tablet tambah darah, 23 responden $(68 \%)$ memberikan jawaban yang salah, hal ini disebabkan karena kurangnya pengetahuan atau informasi kepada ibu yang kurang berpengalaman dalam menangani anemia selama kehamilan. Pada buku Proverawati A yang berjudul Buku Ajar Gizi Untuk Kebidanan, menunjukkan bahwa akibat yang akan timbul saat bersalin adalah gangguan his primer dan sekunder, janin lahir dengan anemia, persalinan dengan tindakan, ibu cepat lelah, dan gangguan persalinan perlu tindakan operatif (Proverawati, 2009).

Pada pertanyaan soal nomor 24 tentang akibat yang timbul setelah melahirkan jika kekurangan tablet tambah darah, 28 responden $(82 \%)$ menyatakan tidak mengetahui tentang akibat yang timbul setelah melahirkan jika kekurangan tablet tambah darah, hal tersebut dapat disebabkan karena kurangnya informasi dan pengalaman yang didapatkan oleh respondenuntuk mencegah anemia saat proses persalinan. Pada buku Proverawati A yang berjudul Buku Ajar Gizi Untuk Kebidanan, menunjukkan bahwa akibat yang timbul setelah ibu melahirkan yang kekurangan tablet tambah darah adalah perdarahan, retensio plasenta, perlukaan sukar sembuh, terjadi febris puerpuralis, dan involusi uteri (Proverawati, 2009).

Sedangkan pada soal nomor 28 tentang waktu ibu hamil mengkonsumsi tablet tambah darah, 19 responden $(56 \%)$ memberikan jawaban salah, ini dikarenakan ketidaktauan ibu mengenai konsumsi tablet Fe. Perlu diketahui bahwa dalam mengkonsumsi tablet $\mathrm{Fe}$ dimulai sejak trimester ke dua, dikarenakan pada trimester pertama ibu masih mengalami mual dan muntah sehingga dalam mengkonsumsi tablet tambah darah dimulai pada trimester kedua. Pada buku Hellen Varney yang berjudul Asuhan Kebidanan menunjukkan bahwa ibu hamil trimester pertama mengalami mual dan muntah dan pada trimester kedua ibu hamil sudah 


\section{Paritas}

Paritas adalah faktor penting dalam menentukan nasib dari ibu dan janin selama kehamilan dan melahirkan. Paritas $\geq 3$ merupakan faktor terjadinya anemia. Hasil penelitian menurut distribusi paritas menunjukkan bahwa persentase terbanyak responden memiliki paritas $<3$. Hal tersebut sesuai dengan teori yang menyatakan bahwa semakin sedikit paritas maka kemungkinan terjadinya anemia semakin kecil karena cadangan zat gizi dalam tubuh masih banyak. Dan juga terdapat paritas $\geq 3$ ini menunjukkan semakin sering seorang wanita melahirkan maka makin banyak kehilangan zat besi dan peluang atau resiko terjadinya anemia akan semakin besar, karena dapat menguras cadangan zat gizi dalam tubuh ibu. Berdasarkan teori Walyani ES paritas adalah jumlah anak yang hidup yang dilahirkan oleh ibu. Jumlah anak merupakan salah satu faktor yang berpengaruh pada partisipasi ibu hamil, karena semakin banyak anak atau lebih dari 1 maka semakin berpengalaman dalam pencegahan anemia (Walyani, 2014).

\section{Pekerjaan}

Pengetahuan seseorang juga dipengaruhi oleh pekerjaan baik secara langsung dan tidak langsung. Menurut teori bahwa pekerjaan menentukan pendapatan seseorang. Hal ini menyebabkan bahwa kurangnya pendapatan seseorang akan mempengaruhi akses untuk membeli bahan makanan yang cukup mengandung zat besi. Selain itu, kurangnya pendapatan ibu juga akan berpengaruh terhadap akses dalam mendapatkan informasi. Dalam penelitian ini sebagian responden bekerja sebagai pegawai swasta, sebenarnya mereka sudah mendapatkan informasi dalam lingkungan kerja, akan tetapi dengan jam kerja yang padat atau tidak menentu maka responden tidak memiliki banyak waktu untuk memastikan kebenaran informasi yang didapat ditempat kerja kepada petugas kesehatan.

\section{SIMPULAN DAN SARAN Simpulan}

Dari penelitian yang telah dilakukan pada ibu-ibu hamil di RS. Panti Wilasa Citarum Semarang tentang Gambaran tingkat pengetahuan ibu tentang anemia dapat di simpulkan:

1. Sebagian besar responden memiliki tingkat pengetahuan yang cukup.

2. Sebagian besar responden berada pada rentang usia 20-35 tahun.

3. Responden sebagian besar pendidikan menengah atas (SMA).

4. Responden sebagian besar dengan paritas $<3$.

5. Responden yang bekerja paling banyak adalah sebagai pegawai swasta.

\section{Saran}

Diharapkan peneliti selanjutnya dapat memperluas judul penelitian seperti hubungan antara pengetahuan dan karakteristik atau hubungan antara pengetahuan dan kepatuhan ibu hamil mengkonsumsi tablet Fe.

\section{DAFTAR PUSTAKA}

Soekidjo N. 2003. Pendidikan dan Perilaku Kesehatan. PT.Rineka Cipta: Jakarta.

Arikunto S. 2002. Prosedur Penelitian Suatu Pendekatan Praktek. PT.Rineka Cipta: Jakarta.

Azwar S. 2011. Sikap manusia teori dan pengukurannya. Ed 2. 
Pustaka pelajar: Yogyakarta.

Achmat Z. 2012. Theory of Planned Behavior, masihkah relevan? Diakses di: http://zakarija.staff.umm.ac .id/files/2010/12/Theory-ofPlanned-Behaviormasihkah-relevan1.pdf pada tanggal 24 Maret 2012

FISHBEIN, M.A. et AJZEN, I. 1975. Belief, attitude, intention and behavior: an introduction to theory and research, Reading, MA, Addison Wesley. Diakses di: http://people.umass.edu/aiz en/f\&a1975.html pada tanggal 24 Maret 2012.

Kementerian Kesehatan Republik Indonesia. 2021. Depkes luncurkan Pusat Data dan Kementerian Kesehatan RI. 22 Desember 2012. [Diakses tanggal 15 September 2015]. Didapat dari:

http://www.depkes.go.id/do wnload.php\%3Ffile\%3Ddo wnload/pusdatin/infodatin/i nfodatin-ibu.pdf

Dinas Kesehatan Provinsi Jawa Tengah. 2015. Profil kesehatan Jawa Tengah. [Diakses tanggal 15 September 2015]. Didapat dari:

http://www.dinkesjatengpro v.go.id

Hasil Riskasdes 2013 terkait kesehatan ibu. [Diakses tanggal 16 Desember 2015]. Didapat dari: http://www.kesehatanibu.de pkes.go.id/archives/678

Metrotvnews. 2013. Prevalensi anemia di Indonesia tinggi. [Diakses tanggal 17 September 2015]. Didapat dari:

http://www.metrotvnews.co $\mathrm{m} / \mathrm{read} / 2013 / 04 / 03 / 143398 /$ prevalensi-anemia-diindonesia-tinggi

Dinas Kesehatan Lumajang. 2013. Ruang Berbagi Dinas Kesehatah Kabupaten Lumajang. [Diakses tanggal 18 September 2015]. Didapat dari:

http://dinkeslumajang.or.id/ anemia-pada-bumil/

Proverawati A. 2009. Buku Ajar Gizi Untuk Kebidanan. Yogyakarta: Nuha Medika; h. $76-0,37-8,78$

Muliarini P. 2010. Pola Makan dan Gaya Hidup Sehat Selama Kehamilan. Yogyakarta: Nuha Medika; h. 112-3

Manuaba IBG. 2007. Pengantar Kuliah Obstetri. Jakarta: EGC; h. 38-9

Purbadewi L, Yn.Setiawati. 2013. Hubungan Tingkat Pengetahuan

AnemiaDengan Kejadian Anemia Pada Ibu Hamil. [Diakses tanggal 20 Oktober 2015]. Didapat dari:

http://jurnal.unimus.ac.id/in dex.php/jgizi/article/view/7 $54 / 808$ 
Susilowati F. 2012. Tingkat Pengetahuan

Ibu Hamil Tentang Anemia

Di Puskesmas Gambirsari

Surakarta. [Diakses tanggal

21 Oktober 2015]. Di dapat dari:

http://digilib.stikeskusumah usada.ac.id/files/disk1/2/01 -gdlfrdinasuli-66-1-ktifrdi.pdf

Hidayah W, Anasari T. 2012. Hubungan Kepatuhan Ibu Hamil MengkonsumsiTablet $\mathrm{Fe}$ Dengan Kejadian Anemia Di Desa Pageraji Kecamatan Cilongok Kabupaten Banyumas. [Diakses tanggal 21 Oktober 2015]. Didapat dari:

http://download.portalgarud a.org/article.php?article $=20$

$0736 \&$ val $=6633 \&$ title

Wawan A, M Dewi. 2011. Teori dan pengukuran pengetahuan, sikap, danperilaku manusia. Yogyakarta: Nuha Mediha; h. 11-8

Ariani P A. 2014. Aplikasi metodologi penelitian kebidanan dan kesehatan reproduksi. Yogyakarta: Nuha Medika; h. $17-8,60-1,67,77-9$

Prawirohardjo S. 2011. Ilmu Kebidanan. Jakarta: PT. Bina Pustaka Sarwono Prawirohardjo; h. 213

Kuswanti I. 2014. Asuhan Kehamilan. Yogyakarta: Pustaka Pelajar; h. 99,104, 20-1, 7
Setiawati S. 2013. Tingkat Pengetahuan Ibu Hamil Trimester III TentangAntenatal Care di RSUD Surakarta. [Diakses tanggal 31 Desember 2013]. Didapat dari: http://digilib.stikeskusumah usada.ac.id/files/disk1/8/01 -gdl-sintasetia-390-1sintase-9.pdf

Marmi. 2011. Asuhan kebidanan patologi. Yogyakarta: Pustaka Pelajar; h.54

Soebroto I. 2009. Cara mudah mengatasi anemia. Yogyakarta: Penerbit Bangkit; h. 55-2

Erwin P. 2013. Hubungan Antara Tingkat Pengetahuan Anemia Dan Sikap Ibu Hamil Dalam Mengkonsumsi Tablet $\mathrm{Fe}$ Dengan Kejadian Anemia Di Wilayah Kerja Puskesmas Kerjo Kabupaten Karanganyar. [Diakses tanggal 15 juni 2016]. Di Dapat dari: http://eprints.ums.ac.id/270 88/22/NASKAH_PUBLIK ASI.pdf

Titaley CR, dkk. 2014. Persepsi Ibu Hamil Dan Nifas Tentang Anemia Dan Konsumsi Tablet Tambah Darah Selama Kehamilan : Studi Kualitatif Di Kabupaten Purwakarta Dan Lebak. Agustus 2014. [Diakses tanggal 15 juni 2016]. Di Dapat dari:download.portalgaruda .org/article.php?article $=324$ $876 \&$ val $=4886 \&$ title $=$ 
Asyirah S. 2012. Faktor-Faktor Yang Berhubungan Dengan Anemia Pada Ibu Hamil Di Wilayah Kerja Puskesmas Bajeng Kecamatan Bajeng Kabupaten Gowa. [Diakses tanggal 1 November 2015]. Di dapat dari: related:lib.ui.ac.id/file?file $=$ digital/20314687-

S_Sitti\%20Asyirah.pdf

Varney H,dkk. 2007. Buku Ajar Asuhan Kebidanan Edisi 4. ECG: Penerbit Buku Kedokteran; h.501-4

Susanti D. 2013. Tingkat Pengetahuan Ibu Multigravida mengkonsumsi Tabllet Fe di Puskesmas Polanharjo Klaten. [diakses tanggal 31 september 2015]. Didapat dari:

http://digilib.stikeskusumah usada.ac.id/

M. Faruq Adi Wibowo. 2010. Pengaruh Suplementasi Tablet Besi dan Vitamin $C$ Terhadap Peningkatan Kadar Hemoglobin Pada Siswa Kelas VI SDN Klego 01 Kota Pekalongan.[diakses tanggal 22 Juni 2016]. Didapat dari: http://lib.unnes.ac.id/2478/1 13435.pdf

Happy DA,dkk. 2015. Penyuluhan Kesehatan Dan Deteksi Anemia Bagi Ibu Hamil Disokaraja Tengah Banyumas. [Diakses Tanggal 15 Juni 2016]. Di Dapat Dari:Http://Download.Porta
lgaruda.Org/Article.Php?Ar ticle $=362960 \& \mathrm{Val}=7672 \&$

Title $=$

Siti Z,dkk. 2015. Hubungan Karakteristik, Paritas Dan Pengetahuan Dengan Upaya Mengatasi Mual Muntah Pada Kehamilan Trimester I Dengan Hiperemesis Gravidarum Di Rumah Sakit Pku Muhammadiyah Gubug Kabupaten Grobogan. [Diakses tanggal 16 juni 2016]. Di Dapat dari: http://digilib.unimus.ac.id/fi les/disk1/165/jtptunimusgdl-sitizaerot-8236-1hubungan-).pdf

Walyani ES. 2014. Asuhan Kebidanan Pada Ibu Hamil. Yogyakarta:

Pustakabarupres; h.69-4

Rahmawati A. 2013. Tingkat Pengetahuan Ibu Hamil Trimester I Tentang TabletFe Di BPM Puji Setiani Tegalmulyo Mojosongo Surakarta. [diakses tanggal 1 november 2015]. Di dapat dari:

http://digilib.stikeskusumah usada.ac.id/files/disk1/8/01 -gdl-agustyarah-368-1ktiagus-i.pdf

Puspitaningsih D. 2011. Hubungan Pengetahuan Tentang Anemia, Pendidikan Ibu, Konsumsi Tablet $\mathrm{Fe}$ Dengan Kadar HB Pada Ibu Hamil Trimester I-III Di RB Bhakti Ibu Kota Semarang. [Diakses tanggal 11 
November 2015]. Di dapat

dari:

http://digilib.unimus.ac.id/fi les/disk1/128/jtptunimusgdl-dewipuspit-6373-1artikel.pdf

Sulistyaningsih. 2011. Metode penelitian kebidanan kuantitatifkualitatif. Yogyakarta: Graha Ilmu; h. 55, 122, 145$6,150-2$

Setiawan A, Saryono. 2011. Metodologi penelitian kebidanan DIII, DIV, S1, dan S2. Yogyakarta: Nuha Medika; h. 123,127

Hidayat A. 2014. Metode penelitian kebidanan dan teknik abalisi data. Jakarta: Salemba Medika; h. 114

Utami TW, Anita A. 2013. Gambaran Pengetahuan Ibu Hamil TentangManfaat Tablet Fe di Desa Candi Kecamatan Ampel Kabupaten Boyolali. [Diakses tanggal 21 Oktober 2015]. Didapat dari:

http://journal.akbideub.ac.i d/index.php

Maulida NS. 2013. Hubungan Tingkat Pengetahuan Tentang Anemia Pada Ibu Hamil Dengan Kepatuhan Dalam Mengkonsumsi Tablet Besi ( $\mathrm{Fe}$ ) Di Puskesmas Keling II Kabupaten Jepara. [Diakses tanggal 21 Oktober 2015]. Didapat dari: http://repository.uinjkt.ac.id /dspace/bitstream/1234567
89/26380/1/Maulida\%20Nu r\%20Soraya-fkik.pdf 